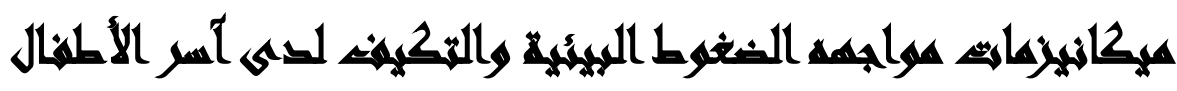

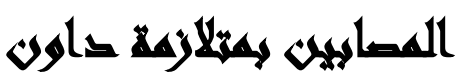

\section{[I Y}

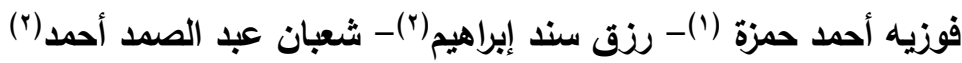

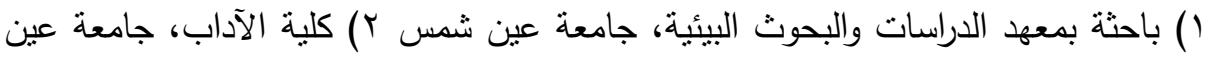

شمس باحس بع:

\section{المسريطلت}

في العقود الماضية كان معظم الأطفال ذوبي متلازمة داون لا يتلقون الرعاية الطبية الكافية

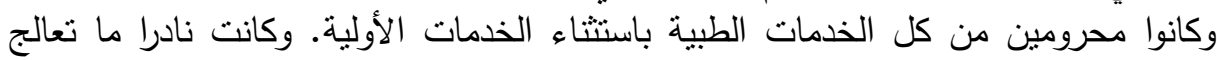

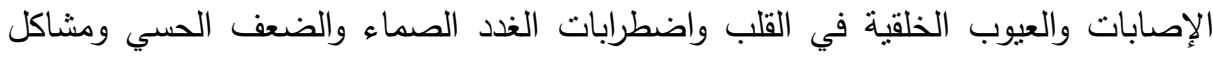

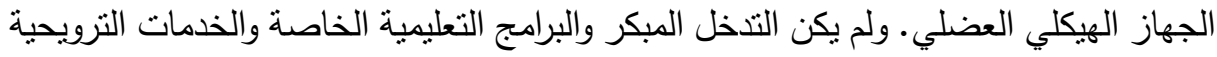

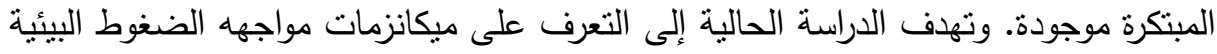

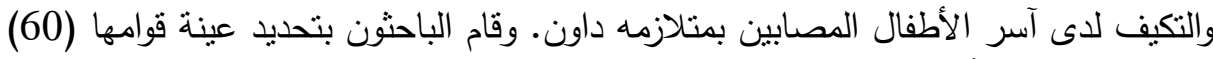

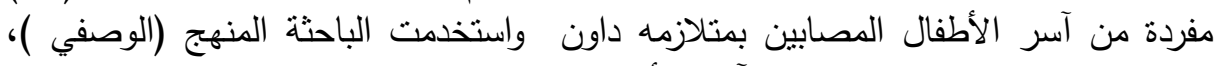

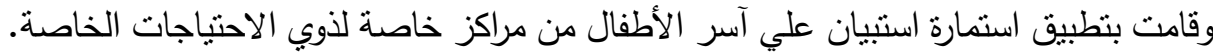

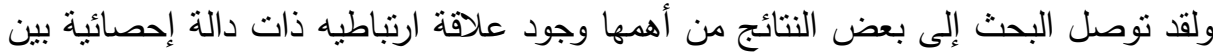

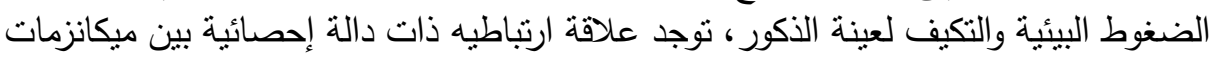

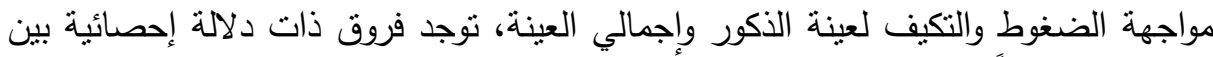

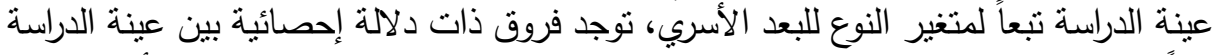

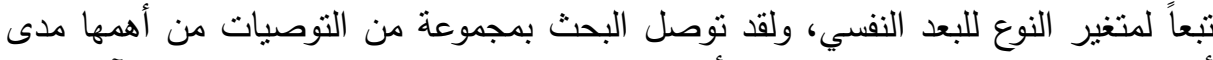

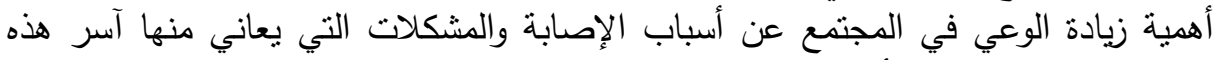

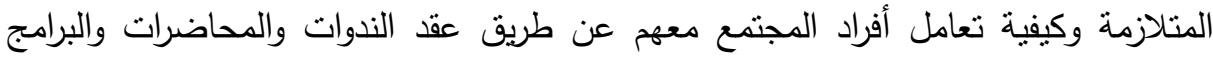

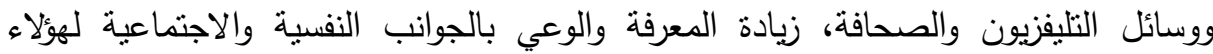

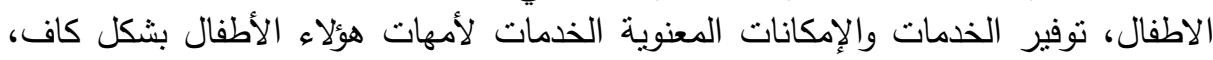

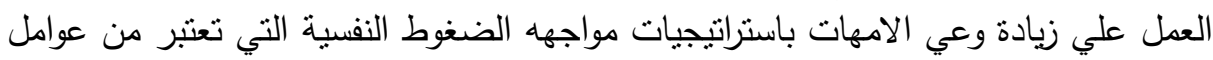

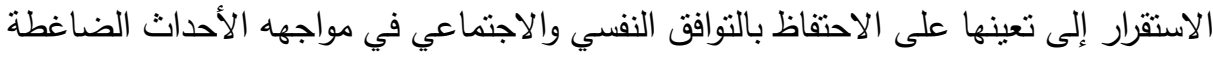




\section{xaxix}

منذ أن تحمل الأم جنينها في أحشائها وهى ترسم خط حياته فهو مكلف بحمل كل أمانيها

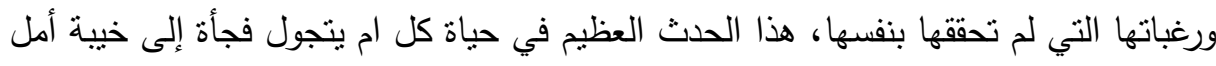
وحزن فتتبخر كل آمالها وطموحاتها من هول المفاجئة، أنه طفل مختلف عن الآخرين لا يشبه والدية أو إخوته أنه مصاب بمتلازمة داون مع ما ماتحمله هذه الإصابة من تبعات.

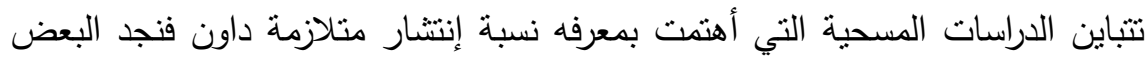

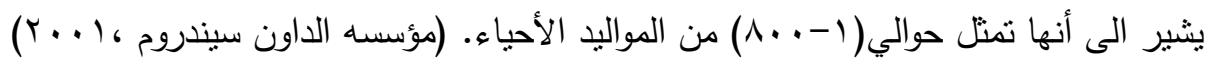

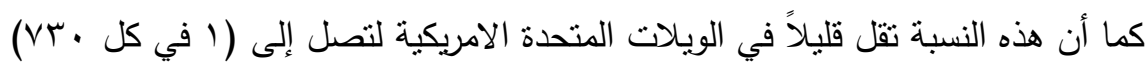

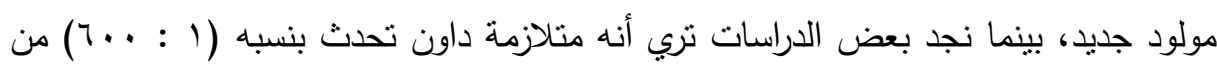

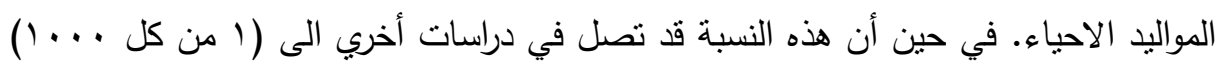

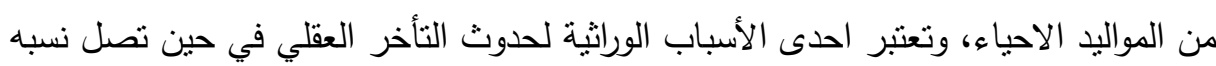

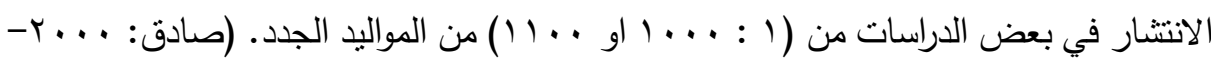
.) ( $1 \leqslant-10$

على سبيل المثال في انجلترا يولد طفلان بمتلازمة داون كل يوم، وفي أمريكا يولد خمسة الأف طفل بمتلازمة داون سنويا، ويولا مائة الف طفل بمتلازمة داون سنويا على مستوي العالم،

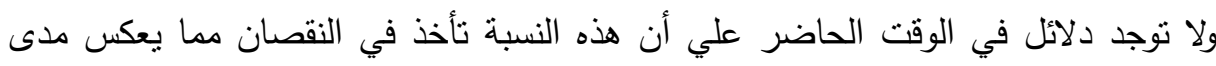

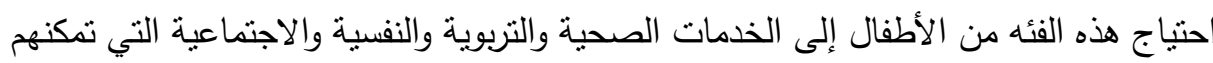
من الحياة بصورة طبيعية مع باقي أفراد المجتمع. (الخطيب :؛ . . . . wishart\&: 2005 )

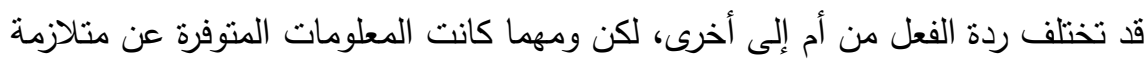

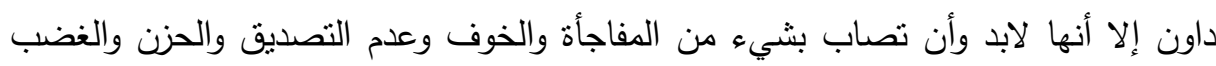

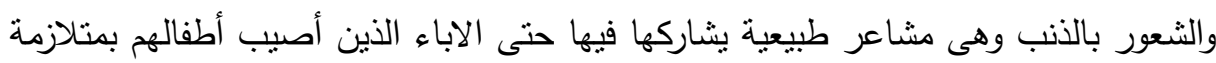
داون. 
أن جميع المصابين بمتلازمة داون يعانون من أعاقه عقلية التي تتفاوت شدتها بين مصاب

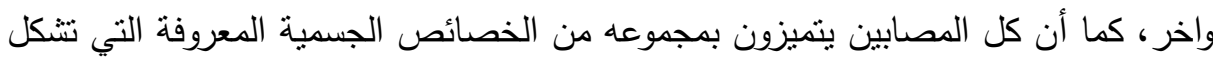

الملامح العامة المميزة لثخصية المصاب بمتلازمة داون. (Www.Werathah.Com) ورغم تطور برامج التربية الخاصة والخدمات التي تقدمها للأطفال ذوى الاحتياجات الخاصة التهات في السنوات الاخيرة، الا أن هذا التطور لم يشمل تقديم الخدمات لأمهات هؤلاء الأطفال بشكل

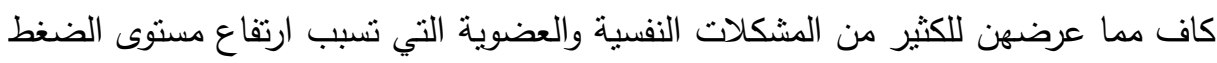

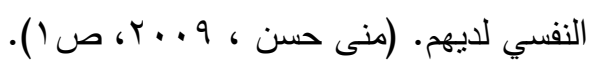

\section{and}

أن مجال ذوي الاحتياجات الخاصة وآسرهم يعد من مجالات الرعاية والخدمة الاجتماعية

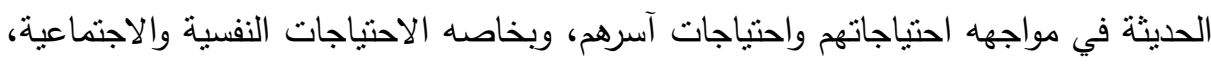
ولعل المشكلات التي تواجه الام التي انجبت طفلا لديه متلازمة داون من بين تلك الاحتياجات

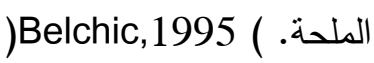

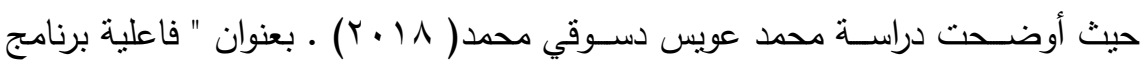
إرشـادي أسـري لنتمية بعض المهارات الحياتية واثره في تحسين السـوك التوافقي لدى الأطفال

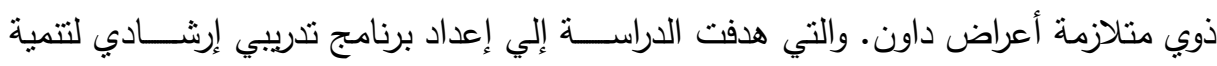

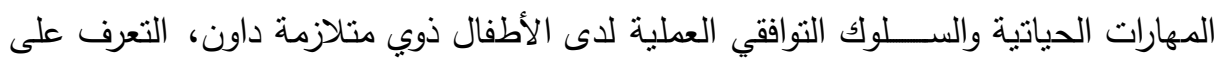

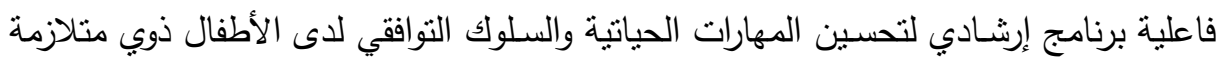
أعراض داون، التعرف على بقاء أثر فاعلية البرنامج المقترح في تحســـين المهارات الحياتية والسلوك التوافقي لدى الأطفال ذوي متلازمة داون، تقديم مقترحات وتوصيات تربوية للاستفادة

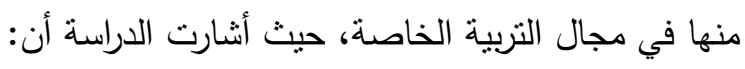

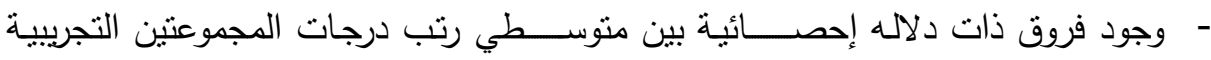

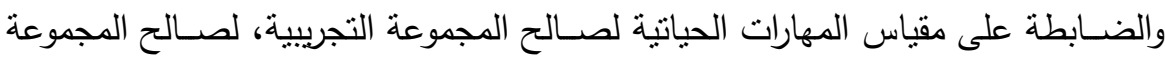


- أيضا وجدت فروق ذات دلالة إحصائية بين متوسطي رثب درجات القياسين القبلي والبعدي

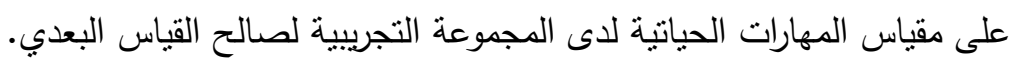

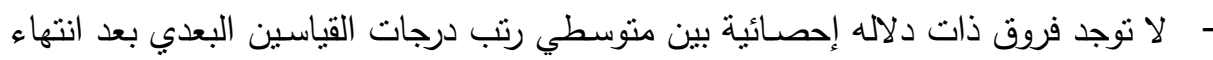

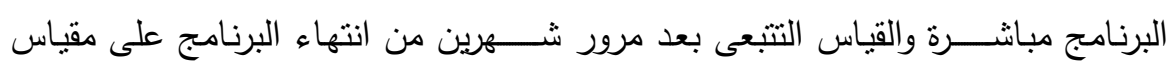

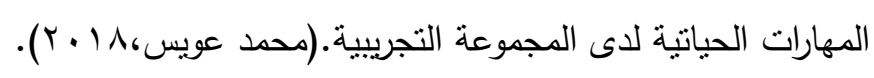

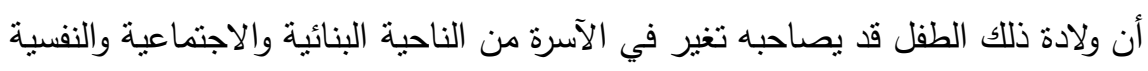

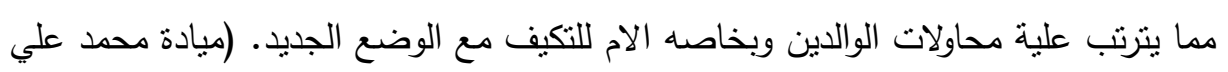

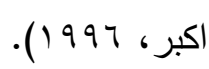
ومن الملاحظ أن ردة الفعل تتفاوت من أم إلى أخري بالرغم من اختلاف المعلومات وتوفرها

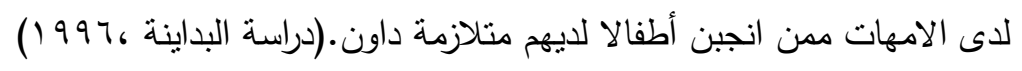

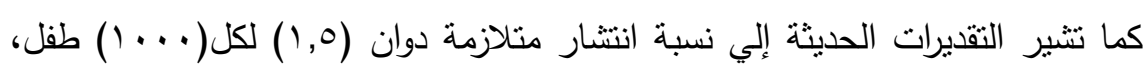

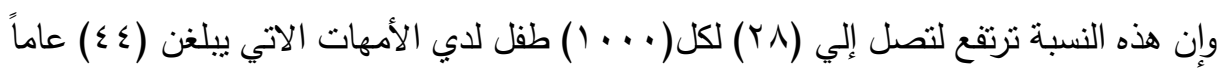

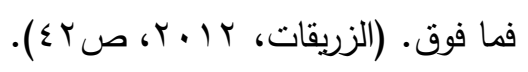

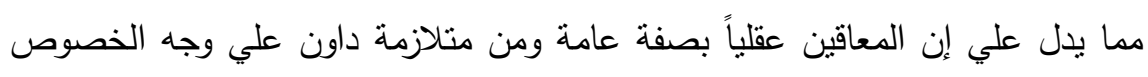

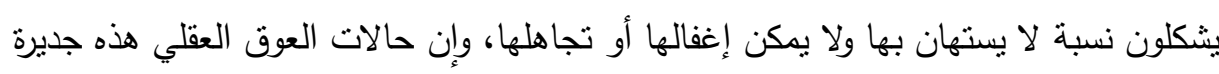

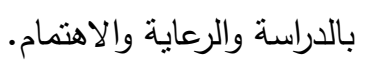
كما أثنارت إحصائيات أخري بأن نسبة الإصابة بمتلازمة داون عالميا بين المواليد الجدد

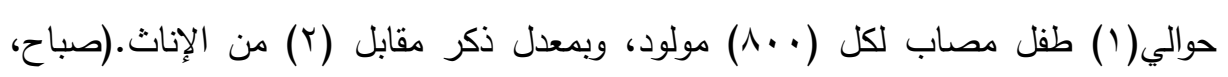

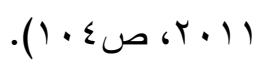
ولكن للأسف الثديد لا توجد احصائيات دقيقة عن المصابين بمتلازمة دوان سواء علي مستوي مصر أو الوطن العربي، مما يجعل هناك غموض في نسبة انتشاره ويصعب الأمور عند وضع الخطة العلاجية له. 


\section{هزوضر اللهمثش}

تتبلور فروض البحث في الفروض الآتية: ا ـ توجد علاقه ارتباطيه ذات داله احصائية بين الضغوط البيئية والتكيف لاي أسر الأطفال المصابين بمتلازمة دوان. r. توجد علاقه ارتباطيه داله في البعد البيئي بين ميكانيزمات مواجهه الضغوط والتكيف لدي

$$
\text { أسر الأطفال المصابين بمتلازمة دوان. }
$$

r. توجد فروق ذات دلاله احصائية بين عينة الدراسة تبعا لمتغير النوع في الضغوط البيئية لدي أسر الأطفال المصابين بمتلازمة دوان. ـ. توجد فروق ذات دلاله احصائية بين عينة الدراسة تبعا لمتغير النوع في التكيف لدي أسر الدران الأطفال المصابين بمتلازمة دوان. ه. توجد فروق ذات دلاله احصائية بين عينة الدراسة تبعا لمتغير النوع في ميكانيزمات مواجهه. الضغوط لدي أسر الأطفال المصابين بمتلازمة دوان.

\section{أهساهث الهيهـ}

\section{تفيب هذه الاراسة في} 1- التعرف على مستوى الضغوط البيئية لأسر الاطفال المصابين بمتلازمة داون.

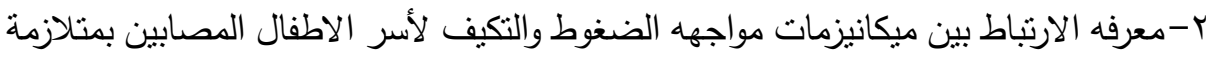

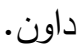
ץ-معرفه الفرق بين الذكور والإناث في التكيف لأسر الاطفال المصابين بمتلازمة داون.

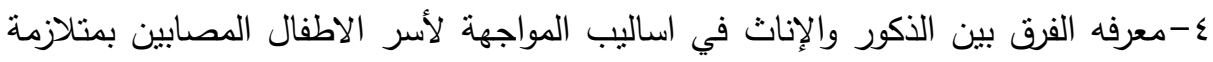

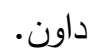




\section{أهمية المهمث}

\section{ينظوي هذا البحث على أهمية من الناحية النظرية والتطبيقية:}

الناحية النظرية:

- - ترجع هذه الأهمية للدور الذي تقوم به الدراسـة من التركيز على آسـر الأطفال (المصـابين

$$
\text { بمتلازمة دوان ) موضع الدراسة. }
$$

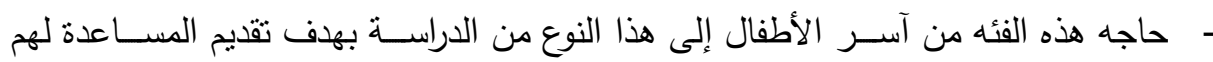

$$
\text { والارشاد النفسي. }
$$

\section{الناحية التطبيقية:}

- تكمن الأهمبة النطبيقية في مساعدة تلك الفئة (آسر الأطفال المصابين بمتلازمه داون) في التخفيف من هذه المشكلات النفسية والاجتماعية التي تعانى منها هذه الآسر وذلك بزيادة التهاعة التها

$$
\text { معرفتهم ووعيهم بالجوانب النفسية والاجتماعية لهؤلاء الاطفال. }
$$

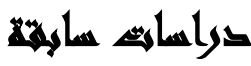

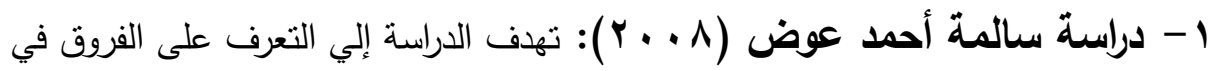

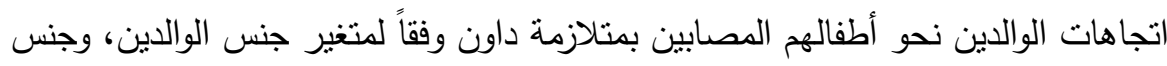

$$
\text { الطفل، وعمر الوالدين، والترتيب الميلادي للطفل. }
$$

أشارت نتائج الدراسة إلي عدم وجود فروق ذات دلالة إحصائية في اتجاهات الوالدين نحو

أطفالهم ذوي الإصابة بأعراض متلازمة داون على الأبعاد: الفهم لطبيعة الإعاقة العقلية- التفاؤل

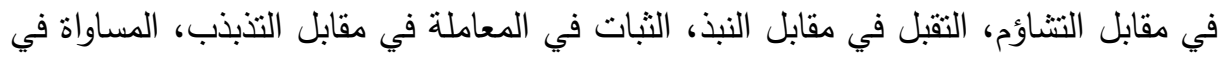
مقابل التقرقة لمقياس اتجاهات الوالدين نحو الإعاقة العقبلة وفقاً لمتغير جنس الوالدين لذوبي الأطفال المصابين بمتلازمة داون. وعدم وجود فروق ذات دلالة إحصائية في اتجاهات الوالدين نحو أطفالهم ذوي الإصابة بأعراض متلازمة داون على الأبعاد: الفهم لطبيعة الإعاقة العقلية-

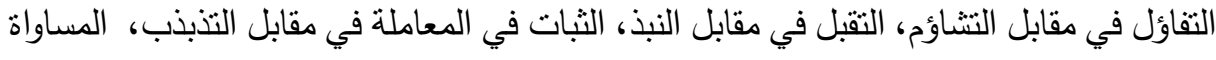
في مقابل التقرقة من حيث المستوى التعليمي للوالدين ذوي الأطفال المصابين بمتلازمة داون. 
وعدم وجود ذات دلالة إحصائية في اتجاهات الوالدين نحو أطفالهم ذوي الإصابة بأعراض متلازمة داون على الأبعاد: الفهم لطبيعة الإعاقة العقلية- التفاؤل في مقابل التشاؤم. r - دراسة دابروشكا وييوسولا ( Dabrowska and Pisula، 2010): تهدف الدراسة إلي قياس الضغوط الوالدية وأساليب التعامل لدى أمهات واباء أطفال ما قبل الدراسة الذين

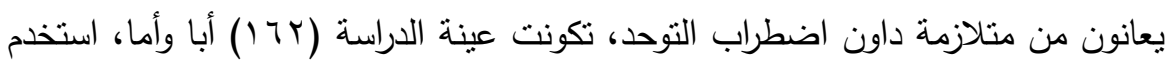
الباحث مقياس مكون من (77) فقرة على شكل استبيان يقيس مستوى الضغوط عند الاباء

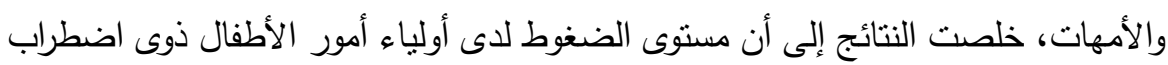

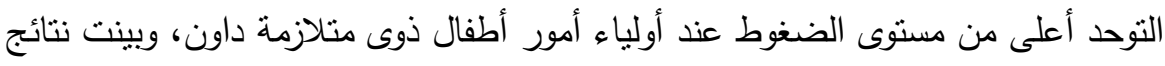

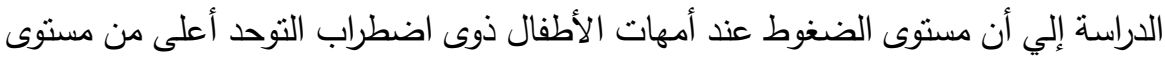

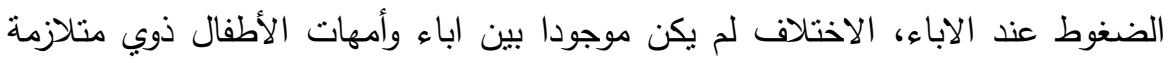
داون، كما بينت الدراسة أن أكثر الضغوط عند أولياء الامور كان التفكير في مدى إمكانية تحسن طفلهم.

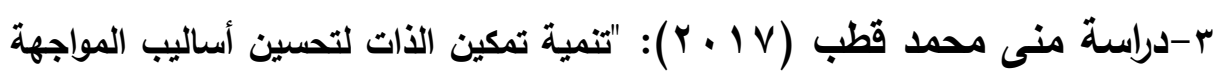
لأمهات اطفال ذوى متلازمة داون.

تهدف الدراسة إلي تتمية تمكين الذات لتحسين أساليب المواجهة لأمهات أطفال ذوى دون

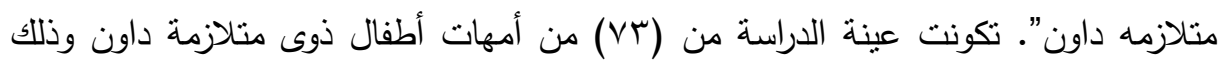

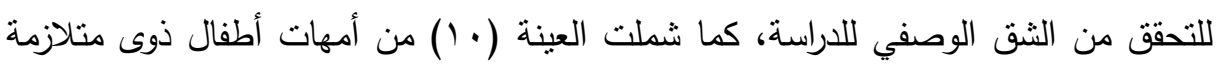

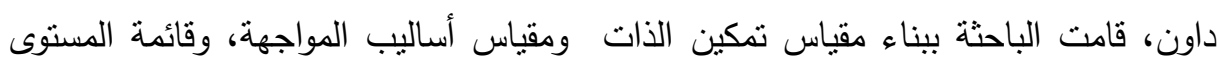

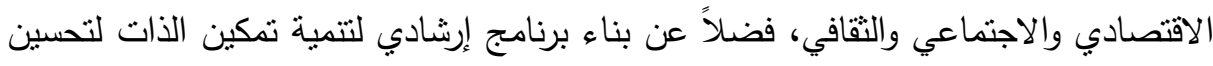

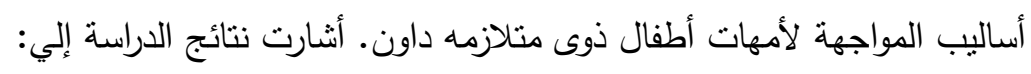

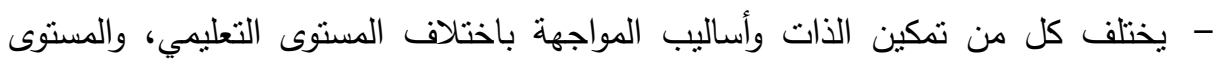
الاقتصادى والاجتماعى، ولم يختلف كل من تمكين الذات وأساليب المواجهة باختلاف الفئات 
- - يختلف كل من تمكين الذات وأساليب المواجهة باختلاف القياسين القبلي والبعدي في اتجاه

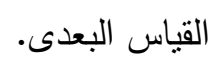

- - يختلف كل من تمكين الذات وأساليب المواجهة باختلاف القياسين البعدي والتتبعى في اتجاه

$$
\text { القياس التتبعى. }
$$

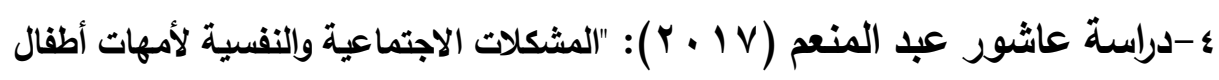

$$
\text { متلازمة داون" }
$$

تهدف الدراسة إلي التعرف على المشكلات الاجتماعية والنفسية التي تواجه أمهات أطفال متلازمة داون والتواصـل الى تصــور مقترح من منظور طريقه العمل مع الجماعات لمســاعدة

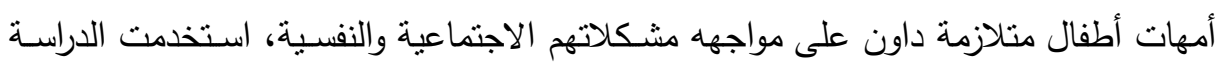

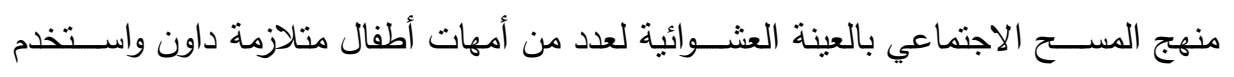

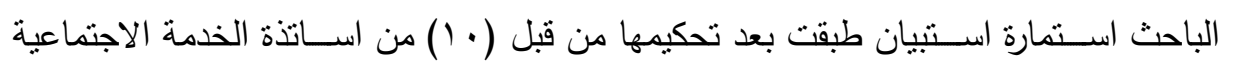

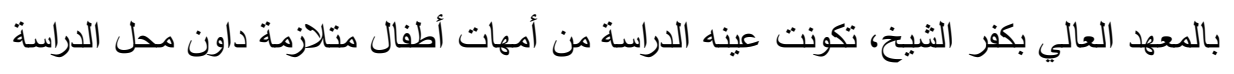

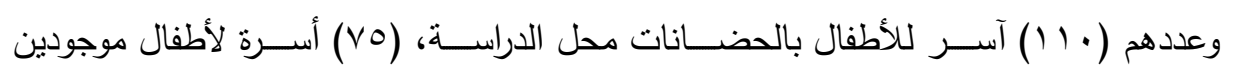

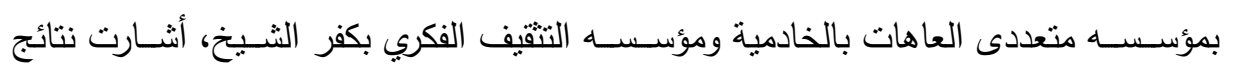

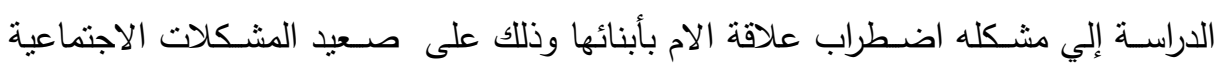

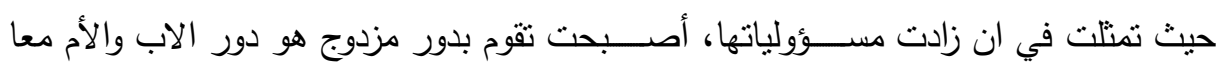
وتثوم بتربيه ابنائها على الاقتداء بابيهم. مشكله اضطراب علاقة الامهات باهلها وأقاربها وذلك على صعيد المشكلات الاجتماعية الهافية

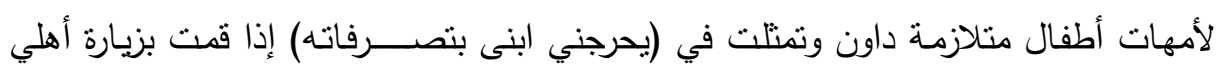

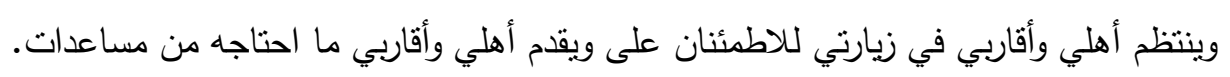

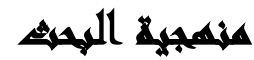

استخدمت الدراسة الحالية المنهج "الوصفي المقارن" لتوضيح أنسب الحلول لمحاولة

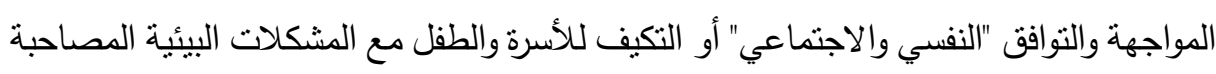

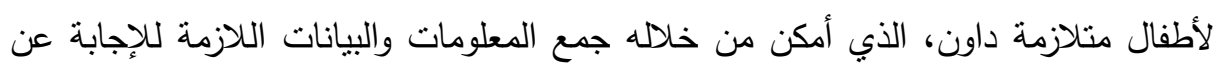


فروض البحث وتحقيق أهدافه، وذللك بالرجوع إلى أدبيات التربية والدارسات ذات الصلة

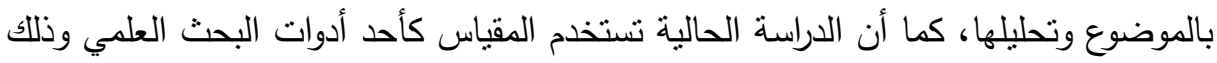
بغرض التعرف على واقع موضع البحث.

\section{هماهمير المهA}

1- الميكاتيزمات: هي الآليات أو الطرق التي تستخدم لمواجهه آسر المرضي لتقبل المرض والتعايش معه حتى يصل لارجه التكيف وتحمل جميع الظروف التى من الممكن يمر بها

$$
\text { الاسرة او المريض. }
$$

r - المواجهة: هي تللك المحاولات التي يستخدمها الثخص للسبطرة على ضغوط المرض ومحاوله تقبلهم للمرض والتعايش معه ومحاوله تقبل فكرة العلاج. r- التكيف: هي استمراريه التواصل الاجتماعي من أفراد العائلة والأصدقاء بعد مرور وقت طويل من العلاج وتخطيهم مع الطفل المصاب.

ع - متلازمة داون: هي حالة جينية ناتجة عن كروموسوم زائد في الخلية، وهذا يعنى أن

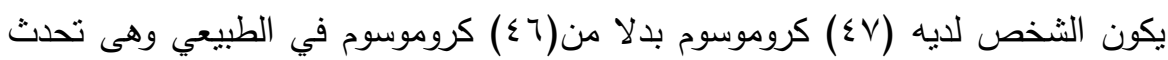

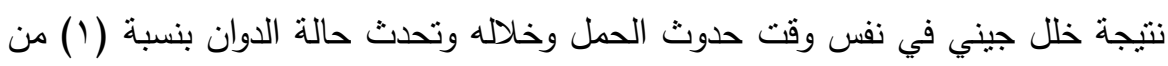

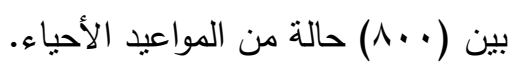

\section{الإطار اللنظلرى للـواسة}

النظريات النفسية المفسرة للاراسة: 1- نظريات الضغوط:

نظريه هانز سبيلي: تعتمد هذه النظرية على أسس فسيولوجية نفسيه، وتعتمد على دراسة الضغوط

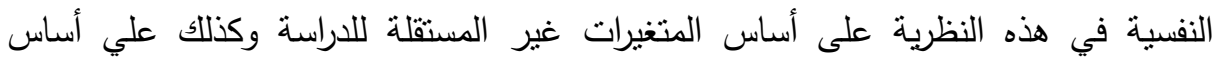
استجابات الفرد للضغوط وعن طريق استجابة الفرد بمكن التتبؤ بمدي وقوع الثخص تحت 
وتعد نظريه هانز سيلى من أهم النظريات التي حاولت فهم الضغوط فقد لاحظ سيلى أن هناك

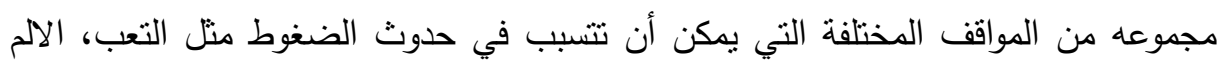
والخوف والثعور بالذل والنجاح غير المتوقع وأثنار إلى أن الضغوط تمنتل تهديدا للفرد وأن

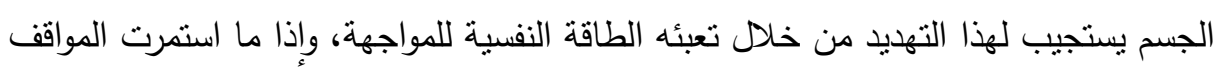
الضاغطة لفترة زمنيه طويله فان استجابة الجسم تظهر في شكل الاجهاد والتعب، وقد تظهر في فئه فئه شكل أعراض سيكوسوماتيه مختلفة وأطلق سيلى على المرحلة التي يمر الكائن في استجابته للضغوط أعراض التكيف العام، حيث تمر بمراحل ثلاث هي: أنيه

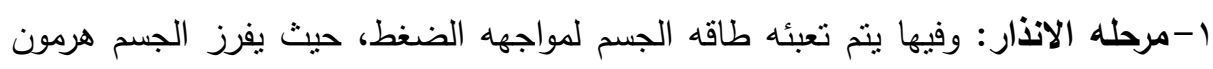

$$
\text { الادرينالين الذى يساعد على الاستعداد على المواجهة. }
$$

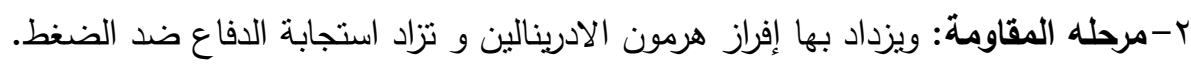
r-مرحله الإتهاك: أي أن مع استمرار استجابة الدفاع عن الجسم واستتفاد الطاقة يصل الكائن

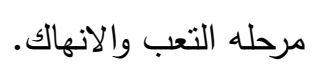

نظرية سيليرجر: تعتمد هذه النظرية على أساس الإدراك الكلى للمواقف، وهو بري أن الضغط

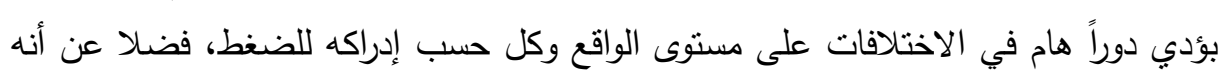

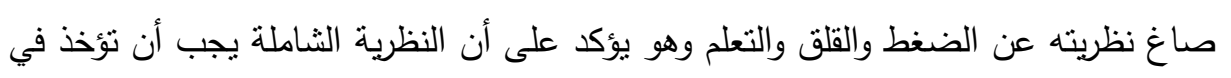
اعتبارها العوامل النالية. 1-طبيعة وأهيمه الضغط في المواقف المختلفة. r-قياس مسنوى شدة القلق الناجم عن الضغط في المواقف المختلفة.

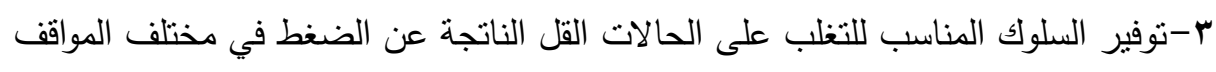
ع -توضيح تأثير الدفاعات السيكولوجية التي يستخدمها الأفراد الذين تجري عليهم التعلم للتخفيف من حالة القلق.

فضلا عن تحديد القوى النسبية للاستجابة الصحيحة والاتجاه الخاطئ الذى ينتج عن التعلم وهكذا لوحظ أن هذه النظرية تركز على المتغيرات المتعلقة بالمواقف الضاغطة وإدراك الفرد لها،

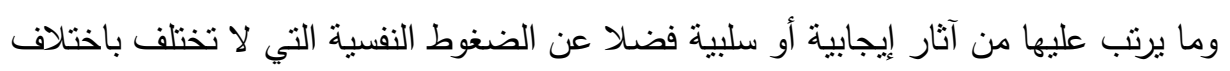


الظروف البيئية والاجتماعية التي تؤثر في المطالب، ولكنها تتأثر الخبرة والاحوال الجسمية والنفسية التى تؤثر في قدرة الكائنات الحية. نظرية سبيلبرجر في القلق تعتبر مقدمة ضرورية لفهم الضغوط، ولذلك نظريته في القلق

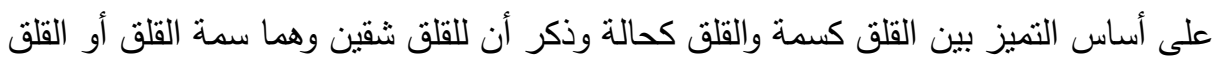
العصبي أو المزمن، وهو استعداد طبيعي أو اتجاه سلوكي يجعل القلق يعتمد بصورة أساسية على الخبرة الماضية، وقلق الحالة وهو قلق موضوعي أو موقفي يعتمد على الظروف الضاغطة التها. نظريات التكبف: نيرة منظوف النظريات المعرفية: ويفترض هذا المنظور وجود نموذجين معرفيين: النموذج الأول أسسه بيك ورفاقه(Beck\&other) ويري بأن سبب الاضطراب النفسي الأفكار السالبة عن الذات،

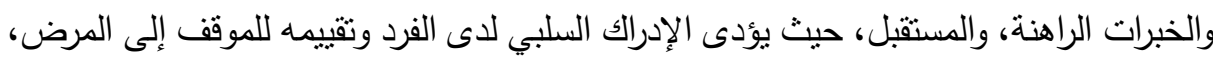

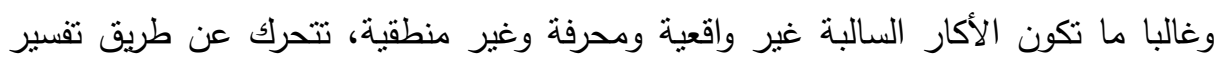

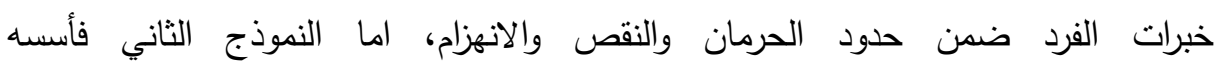
سليجمان( Seligman) ويسمي العجز المتعلم وقلة الحيلة، ويري أن التعرض لإحداث خارجة والتهات عن نطاق السيطرة وادركاها في هذا الإطار يؤدي إلى توقعات عن فقدان السيطرة على الأحداث

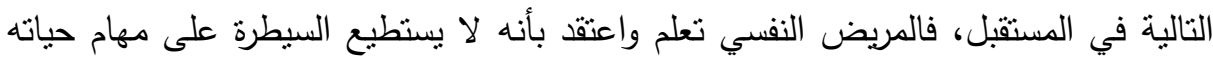

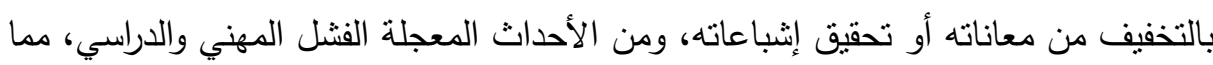

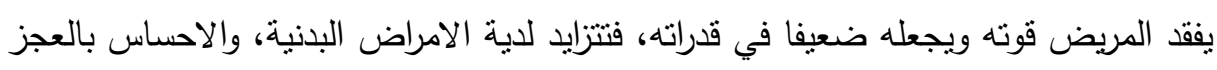

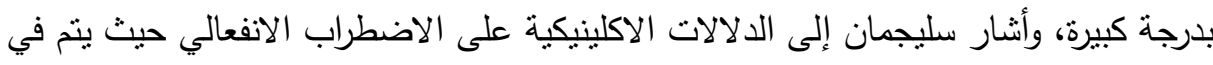

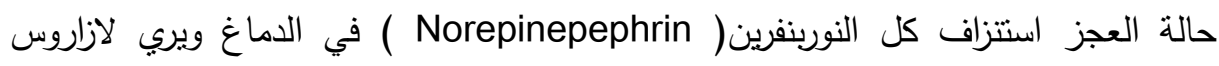

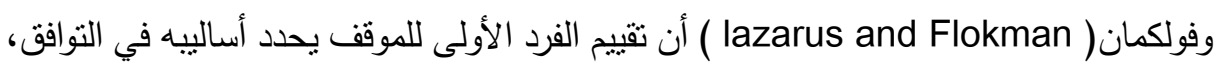
حيث يتم تقييم الفرد للأحداث المسببة للضغط النفسي على أنها مرهقة، أو تفوق قدرته، وتعرضه الضه

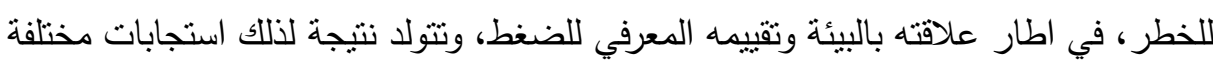

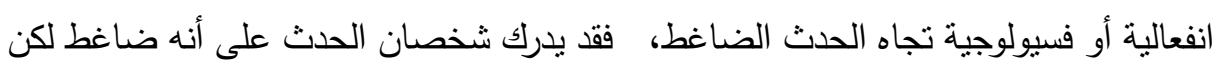


أحدهما يعتقد أن لدية مصادرة وإمكانياته التي تساعده على التعامل معه، بينما لا يعتقد الثخص الاخر ذلك، طبقا لمصادر المواجهة الثخصية والمعرفية والاجتماعية والمادية لدى كل منهم.

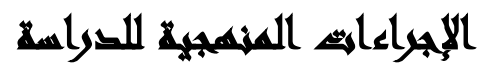

1- نوع الدراسة: تعنتر الدراسة من الدراسات الوصفية لأنها أنسب أنواع الدراسات الملائمة

لطبيعة الظاهرة موضوع الدراسة.

ץ- منهج الاراسة: المستخدم هو المنهج الوصفي المقارن من خلال استخدام عينة من مجتمع الدراسة لبعض آسر الأطفال المصابين بمتلازمة داون.

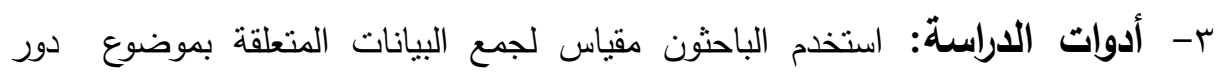
ميكانيزمات مواجهة الضغوط البيئية والتكيف لدي آسر الأطفال المصابين بمتلازمة داون. قام الباحثون باستخدام مصدرين أساسين للمعلومات:

1) المصادر الثانوية: والتي تتمنل في الكتب والمراجع العربية والأجنبية ذات العلاقة والدوريات

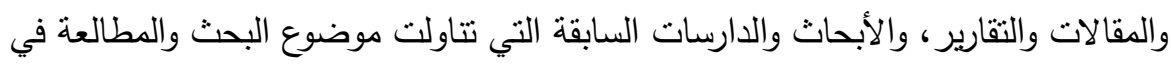

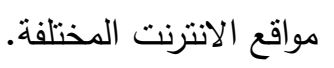

r) المصادر الأولية: والتي تمثلت في جمع البيانات الأولية من خلال اختبار نفسي كاداه رئيسية

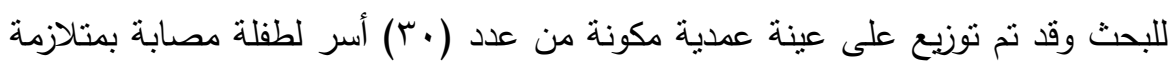
داون، (r) أسر لطفل مصاب بمتلازمة داون، استغرقت فترة جمع البيانات أربعة أثهر لهر

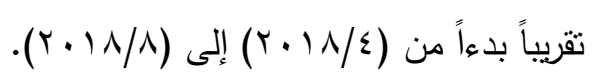

r) وصف أداة القياس: قام الباحثون بنطبيق مقياس الضغوط البيئية للأطفال المصابين

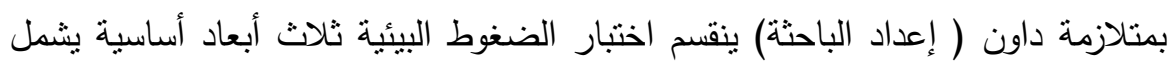

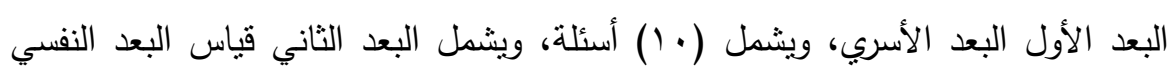

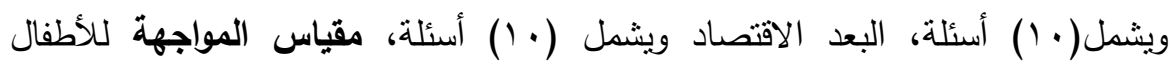

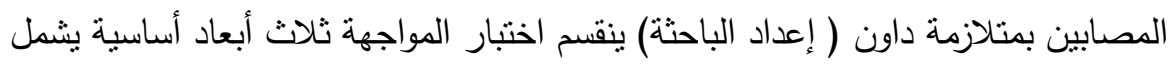
البعد الأول البعد النفسي، ويشمل (• () أسئلة، ويشمل البعد الثاني قياس البعد الاجتماعي إعني

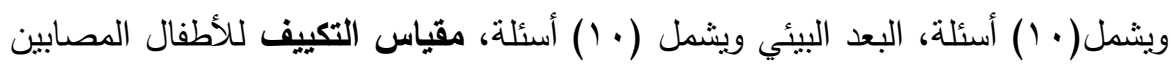


بمتلازمة داون ( إعداد الباحثة) ينقسم اختبار التكييف ثلاث أبعاد أساسية يشمل البعد الأول البعد النفسي، ويشمل (• () أسئلة، ويشمل البعد الثناني قياس البعد الاجتماعي ويشمل( • (1)

$$
\text { أسئلة، البعد البيئي ويشمل (• • (1) أسئلة. }
$$

وقد قام الباحثون بعمل صدق وثبات للأدوات في ضوء البهُ عينة الدراسة الحالية :

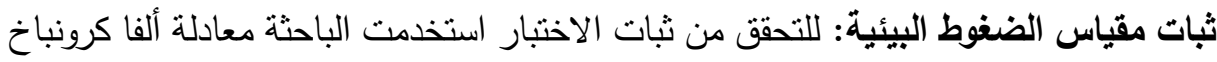
(Alpha Cronbach) جدول (1): ثبات عبارات أبعاد مقياس الضغوط البيئية

\begin{tabular}{|c|c|c|}
\hline قيمةُ ألفا & عدد العبارات & أبعاد المقياس \\
\hline ., $\mathrm{VTM}$ & 1. & البعد الأسري \\
\hline$\cdot, V \cdot V$ & 1. & البعد النفسي \\
\hline$\cdot, \mathrm{V}$ TO & 1. & البعد الاقتصسادي \\
\hline •, АTr & $r$. & إجمالي مقياس الضغوط البيئية \\
\hline
\end{tabular}

يتضح من الجدول السابق أن قيم معاملات الثبات جميعها قيم مقبولة حيث بلغت قيم

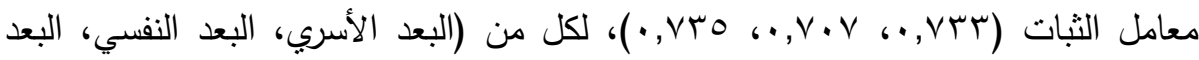

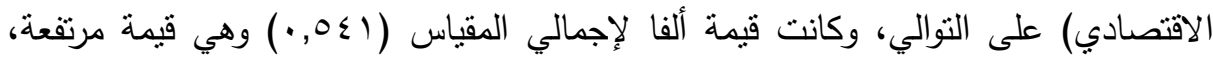

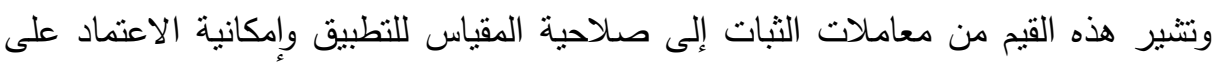

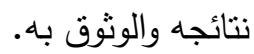
صدق الاتساق الداخلي للمقياس: تم حساب معاملات ارتباط كل بعد من أبعاد الاختبار بالدرجة الكلية للاختبار والتي نتجت عن تطبيق الاختبار على عينة مبئية، وقامت الباحثة بحساب صدق الاتساق الداخلي ومعامل الارتباط المصحح كالآتي: 
جدول (ץ): صدق الاتساق الداخلي لأبعاد مقياس الضغوط البيئية

\begin{tabular}{|c|c|c|}
\hline إجمالي المقياس & \multicolumn{2}{|c|}{ أبعاد المقياس } \\
\hline$\left({ }^{(* *)} \cdot, \wedge, \leq\right.$ & معامل ارتباط بيرسون & Y \\
\hline$\cdot, \ldots 1$ & الدلالة المعنوية & عد الاسري \\
\hline$(* *) \cdot, \vee \vee \vee r$ & معامل ارتباط بيرسون & \\
\hline$\dot{x, \ldots \varepsilon}$ & الدلالة المعنوية & \\
\hline$\left({ }^{* *}\right) \cdot, \vee \backslash \wedge$ & معامل ارتباط بيرسون & \\
\hline$\overline{., \ldots 1}$ & الدلالة المعنوية & \\
\hline
\end{tabular}

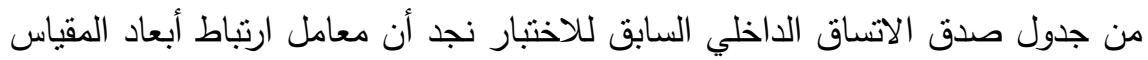

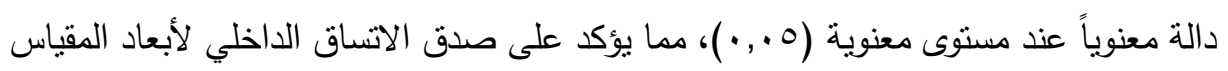

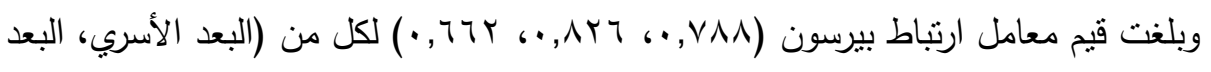
النفسي، البعد الاقتصادي) على النوالي. ثبات مقياس التكيف: للتحقق من ثبات الاختبار استخدمت الباحثة معادلة ألفا كرونباخ

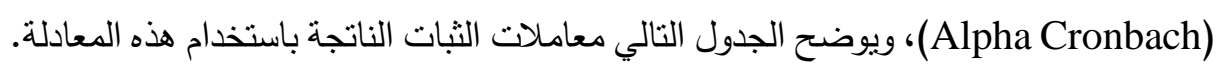
جدول (r): ثبات عبارات أبعاد مقياس التكيف

\begin{tabular}{|c|c|c|}
\hline قيمة ألفا & عدد العبارات & أبعاد المقياس \\
\hline$\cdot, 7 Y \Lambda$ & 1. & البعد النفسي \\
\hline$\cdot, V Y M$ & 1. & البعد الاجتماعي \\
\hline$\cdot, 704$ & 1. & البعد البيئي \\
\hline., 094 & $r \cdot$ & إجمالي مقياس التكيف \\
\hline
\end{tabular}

يتضح من الجدول السابق أن قيم معاملات الثبات جميعها قيم مقبولة حيث بلغت قيم النيف

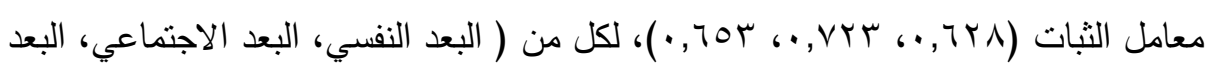

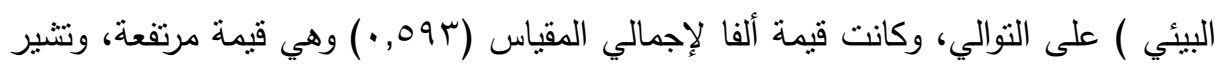
هذه القيم من معاملات الثنات إلى صلاحية المقياس للنطبيق وإمكانية الاعتماد على نتائجه والوثوق به. - ماته صدق الاتساق الاخلي للمقياس: نم حساب معاملات ارتباط كل بعد من أبعاد الاختبار بالدرجة

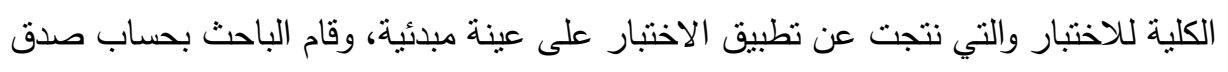
الاتساق الداخلي ومعامل الارتباط المصحح كالآتي: 


\begin{tabular}{|c|c|c|}
\hline إجمالى المقياس & \multicolumn{2}{|c|}{ آبعاد المقياس } \\
\hline$(* *) \cdot, 719$ & معامل ارتباط بيرسون & \multirow{2}{*}{ البعد النفسي } \\
\hline$\cdot, \cdots$, & الدلالة المعنوية & \\
\hline$(* *) \cdot, 797$ & معامل ارتباط بيرسون & \multirow{2}{*}{ البعد الاجتماعي } \\
\hline$\cdot, \cdots \varepsilon$ & الدلالة المعنوية & \\
\hline$(* *) \cdot, 77 \varepsilon$ & معامل ارتباط بيرسون & \multirow{2}{*}{ البعد المنزلي } \\
\hline$\cdot, \ldots 1$ & الدلالة المعنوية & \\
\hline
\end{tabular}

من جدول صدق الاتساق الداخلي السابق للاختبار نجد أن معامل ارتباط أبعاد المقياس

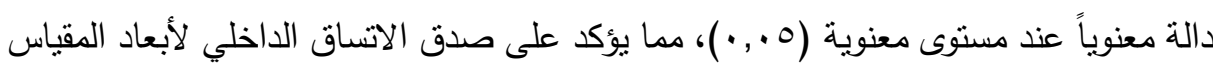

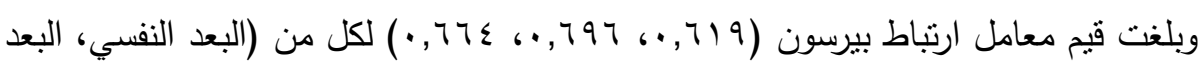

$$
\text { الاجنماعي، البعد المنزلي) على التوالي. }
$$

ثبات مقياس المواجهة: للتحقق من ثبات الاختبار استخدمت الباحثة معادلة ألفا كرونباخ جأول) ويوضح الجدول التالي معاملات الثبات الناتجة باستخدام هذه المعادلة. جدول (•): ثبات عبارات أبعاد مقياس المواجهة

\begin{tabular}{|c|c|c|}
\hline قيمة ألفا & عدد العبارات & أبعاد المقياس \\
\hline$\cdot, 791$ & 1. & البعد النفسى \\
\hline$\cdot, 7 \wedge \uparrow$ & 1. & البعد الاجتماعى \\
\hline$\cdot, T Y Y$ & $1 \cdot$ & البعد البيائي \\
\hline$\cdot, \vee Y \wedge$ & $r$ r. & إجمالى مقياس المواجهة \\
\hline
\end{tabular}

يتضح من الجدول السابق أن قيم معاملات الثبات جميعها قيم مقبولة حيث بلغت قيم الثيم

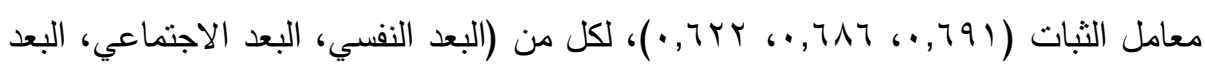

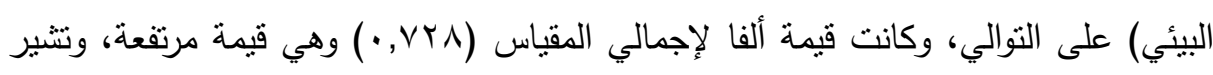
هذه القيم من معاملات الثبات إلى صلاحية المقياس للتطبيق وإمكانية الاعتماد على نتائجه

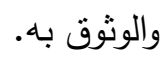

صدق الاتساق الداخلي للمقياس: نم حساب معاملات ارتباط كل بعد من أبعاد الاختبار بالدرجة

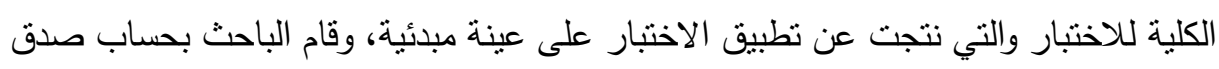
الاتساق الداخلي ومعامل الارتباط المصحح كالآتي: لإني 
جدول (†): صدق الاتساق الداخلي لأبعاد مقياس المواجهة

\begin{tabular}{|c|c|c|}
\hline إجمالى المقياس & \multicolumn{2}{|c|}{ آبعاد المقياس } \\
\hline$\left({ }^{(* *)}\right),, \wedge \leq \Gamma$ & معامل ارتباط بيرسون & \\
\hline$\cdot, \cdots 1$ & الد لالة المعنوبة & البعد النقسي \\
\hline$\left({ }^{* * *}\right) \cdot, \Lambda \cdot V$ & معامل ارتباط بيرسون & \\
\hline$\cdot, \ldots \leqslant$ & الد لالة المعنوبية & بعد الإ \\
\hline$\left.\left({ }^{* * *}\right),, V Y\right)$ & معامل ارتباط بيرسون & \\
\hline$\cdot,, \cdots 1$ & الدلالة المعنوية & بعد البيئي \\
\hline
\end{tabular}

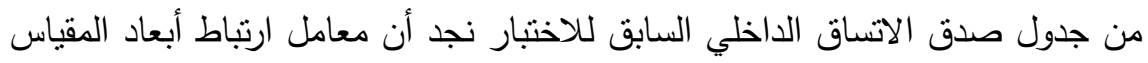

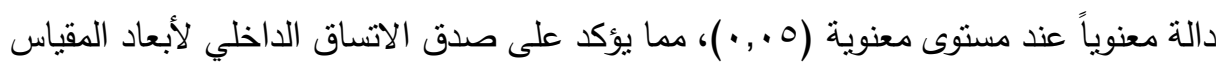

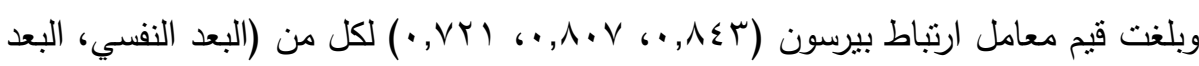

$$
\text { الاجتماعي، البعد البيئي) على التوالي. }
$$

ه-المجال البشري: تكونت عينة الدراسة من (•ج) مفردة موزعة كالآتي (•r) إناث (•r) ذكور المرافقين للأطفال.

צ-المجال المكاني: منطقة القاهرة حيث تم اختيار عدد (r) مراكز خاصه لذوي الاحتياجات

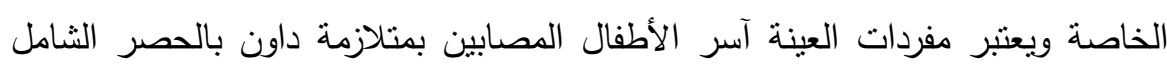

$$
\text { بالمراكز المختارة. }
$$

\begin{tabular}{|c|c|c|}
\hline الموقع & المراكز المختارة & p \\
\hline حدائق القبه -القاهرة & مركز التثقيف الفكري & 1 \\
\hline جامعه عين شمس & مركز الاحتياجات الخاصة & $r$ \\
\hline المطرية -القاهرة & المؤسسة القومية لتتمية الاسرة والمجتمع & $\mu$ \\
\hline
\end{tabular}

جدول (V): المراكز المختارة بمحافظة القاهرة

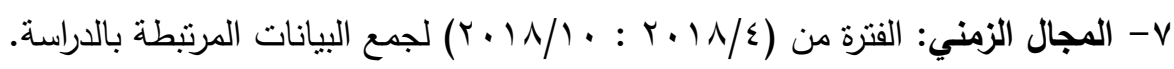
^-شروط العينة: قد أخذ الباحثون عينة عمدية مقصودة عشوائية لأسر الأطفال المصابين

بمتلازمة داون

وقد راعت الدراسة الثروط التالية: باندان - أن تكون عينه الدراسة من (الاب - الام ) المرافق للطفل.

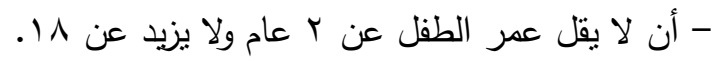

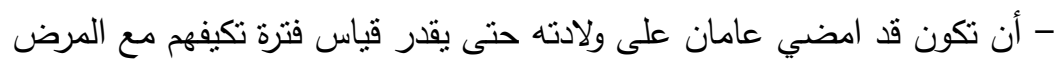


1 - 1 - خصائص عينة الدراسة:

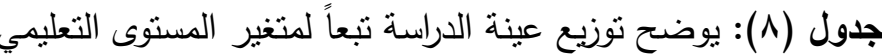

\begin{tabular}{|c|c|c|}
\hline النسبة & العدد & النوع \\
\hline$\% 0$. & $r$. & ذكور \\
\hline$\% 0^{0}$. & $r$. & إناث \\
\hline$\% 1 \ldots$ & 7. & الإجمالي \\
\hline
\end{tabular}

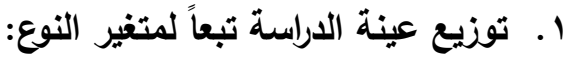

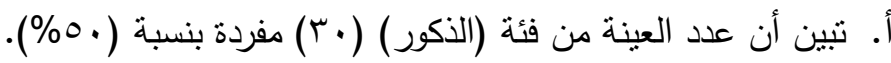
ب. عدد العينة من فئة (الإناث) (· (r) مفردة بنسبة ( • \%\%). جدول (9): يوضح توزيع عينة الدراسة تبعاً لمتغير السن

\begin{tabular}{|c|c|c|c|c|c|c|}
\hline \multicolumn{2}{|c|}{ إجمالي } & \multicolumn{2}{|c|}{ 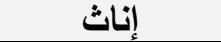 } & \multicolumn{2}{|c|}{ ذكور } & \multirow{2}{*}{ السن } \\
\hline النسبة & 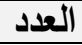 & النسبة & العدد & النسبة & العدد & \\
\hline$\varepsilon 7, V$ & YA & $\varepsilon r, \Gamma$ & $\pi$ & 0. & 10 & آَّل من 1 سنوات \\
\hline$r$ r. & 11 & $r$. & 9 & $\mu$. & 9 & من 7 سنوات - r I سنة \\
\hline$T \mu, \mu$ & $\overline{T \varepsilon}$ & $Y \uparrow, V$ & $\bar{\Lambda}$ & $r$. & 7 & أكبر من Y I سننة \\
\hline$\ldots$ & 7. & $\ldots$ & $r$. & $1 \cdots$ & $r$. & جم \\
\hline \multicolumn{2}{|c|}{$\Lambda, \Lambda \wedge \mu$} & \multicolumn{2}{|c|}{ V,qArr } & \multicolumn{2}{|c|}{ V,qArr } & الوسط الحسابح \\
\hline \multicolumn{2}{|c|}{$\varepsilon, \Gamma Y$} & \multicolumn{2}{|c|}{$\varepsilon, Y Y$} & \multicolumn{2}{|c|}{$\varepsilon, Y Y$} & الانحراف المعياري \\
\hline \multicolumn{2}{|c|}{$r$} & \multicolumn{2}{|c|}{$r$} & \multicolumn{2}{|c|}{$r$} & ل ل قيمة \\
\hline \multicolumn{2}{|c|}{$\overline{T V}$} & \multicolumn{2}{|c|}{$\bar{T}$} & \multicolumn{2}{|c|}{ iv } & e) \\
\hline
\end{tabular}

بالنظر إلي الجدول السابق:

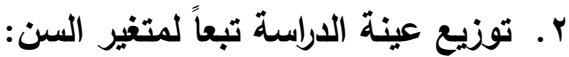

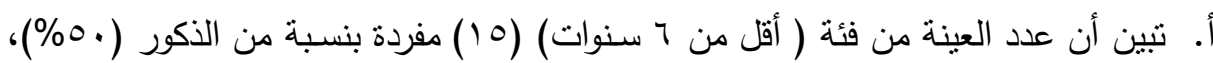

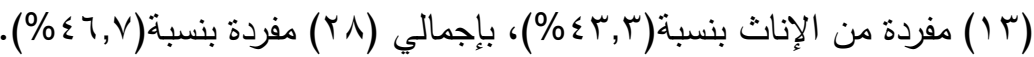

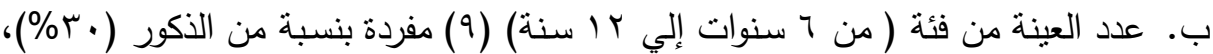

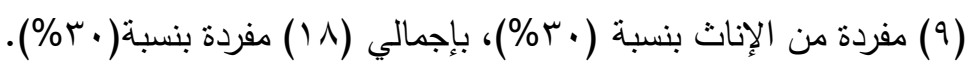

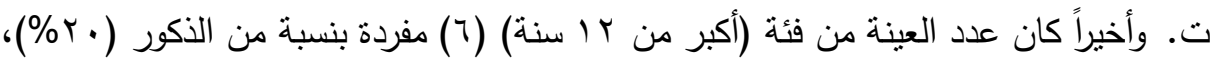

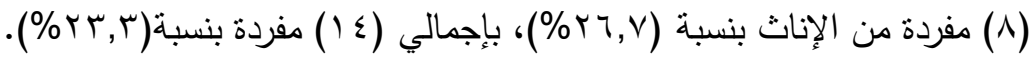

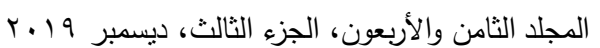




\section{أورايت اللهميد}

نتائج الدراسة:

الفرض الاول: توجد علاقة ارتباطيه ذات دالة إحصائية بين الضغوط البيئية والتكيف لأسر الأطفال المصابين بمتلازمة داون. جدول (• (): العلاقة الارتباطية بين الضغوط البيئية والنكيف دلفين

\begin{tabular}{|c|c|c|c|c|c|c|}
\hline \multicolumn{6}{|c|}{ التكيف } & \multirow{3}{*}{ المتغيرات } \\
\hline$(7 \cdot=\dot{0}$ & إجمالى العينة & \multicolumn{2}{|c|}{ الإناث (ن = + r) } & \multicolumn{2}{|c|}{ الأكور (ن= · r) } & \\
\hline المعنالة المنية & معامل ارتباط & الالالة المعنوية & معامل ارتباط & الالالةية & معامل ارتباط & \\
\hline$\cdot, \cdot V$ & •, YTV & $\cdot, 9$ & צו & $\cdot, \cdot \varepsilon$ & " • " & الضغوط البئية \\
\hline \multicolumn{2}{|c|}{., 07} & \multicolumn{2}{|c|}{$\cdot, \cdots 1$} & \multicolumn{2}{|c|}{$\cdot, 1 T \leq$} & 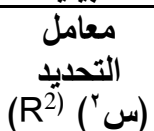 \\
\hline
\end{tabular}

من الجدول السابق لنتائج العلاقة ارتباطية الضغوط البيئية والتكيف يتضح التالي:

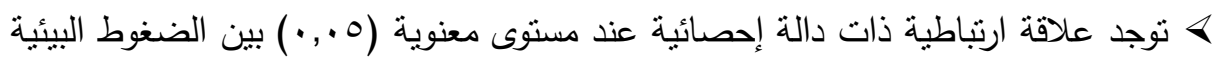

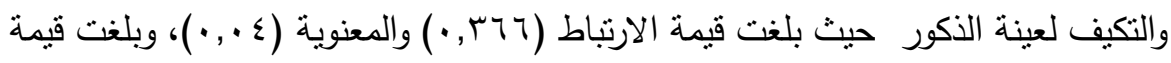

$$
\text { معامل التحديد (ع با, •). }
$$

> لا توجد علاقة ارتباطية ذات دالة إحصائية عند مستوى معنوية (0. . •) بين الضغوط البيئية

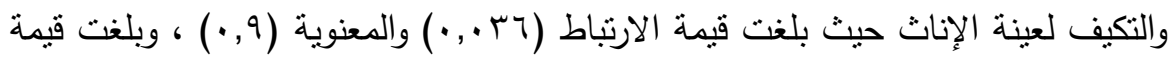

$$
\text { معامل التحديد (1 (.,.•). }
$$

> لا توجد علاقة ارتباطية ذات دالة إحصائية عند مستوى معنوية (0 . . •) بين الضغوط البيئية

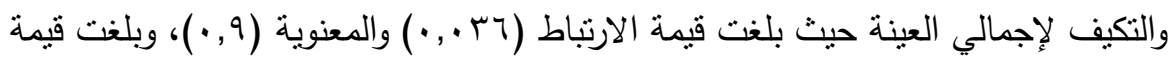

$$
\text { معامل التحديد (07. ., ).). }
$$

مما سبق يتضح تحقق صحة الفرض: نوجد علاقة ارتباطية ذات دالة إحصائية بين الضغوط البيئية والنكيف لعينة الذكور.

بينما لم بتحقق صحة الفرض: توجد علاقة ارتباطية ذات دالة إحصائية بين الضغوط البيئية والتكيف لعينة الإناث وإجمالي العينة. 
مما سبق لم يتحقق صحة الفرض الأول: توجد علاقة ارتباطيه ذات دالة إحصائية بين الضغوط البيئية والتكيف لأسر الاطفال المصابين بمتلازمة داون. الفرض الثاني: توجد علاقة ارتباطية دالة في البعد البيئي بين ميكانزمات مواجهة الضغوط والتكيف.

جلول (11): العلاقة الارتباطية في البعد البيئي بين ميكانزمات مواجهة الضغوط والتكيف

\begin{tabular}{|c|c|c|c|c|c|c|}
\hline \multicolumn{6}{|c|}{ التكيف } & \multirow{3}{*}{ المتغيرات } \\
\hline \multicolumn{2}{|c|}{ 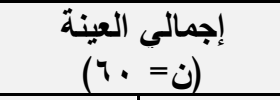 } & \multicolumn{2}{|c|}{ الإناث (ن = • r) } & \multicolumn{2}{|c|}{ الذكور (ن= · · ) } & \\
\hline المعنوية & بيرستباط & المعنوية & بيرسبون & المعنوية & بيرسبون & \\
\hline$\cdot, \cdots)$ & $" ., 09 \mathrm{~V}$ & $\cdot, 99$ & $\cdot, \ldots)$ & $\cdot, \ldots 1$ & $" \cdot, \lambda \mid r$ & ميكانزمات مواجهة \\
\hline \multicolumn{2}{|c|}{ r., } & \multicolumn{2}{|c|}{$\cdot, \ldots}$, & \multicolumn{2}{|c|}{$\cdot, 709$} & معامل التحديد \\
\hline
\end{tabular}

من الجدول السابق لنتائج العلاقة ارتباطية بين ميكانزمات مواجهة الضغوط والتكيف يتضح

ك توجد علاقة ارتباطية ذات دالة إحصائية عند مستوى معنوية (0 . , •) بين ميكانزمات مواجهة

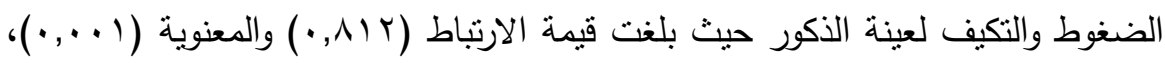

$$
\text { وبلغت قيمة معامل التحديد (1097, • ) ). }
$$

ه لا توجد علاقة ارتباطية ذات دالة إحصائية عند مستوى معنوية (0., •) بين ميكانزمات

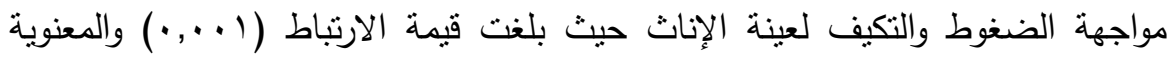

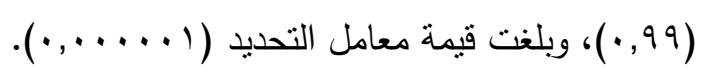

ك توجد علاقة ارتباطية ذات دالة إحصائية عند مستوى معنوية (0 . . • ) بين ميكانزمات مواجهة

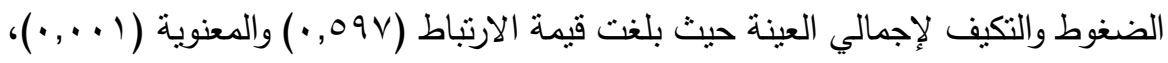

$$
\text { وبلغت قيمة معامل التحديد (لإهب, •) ). }
$$


مما سبق يتضح تحقق صحة الفرض: توجد علاقة ارتباطية ذات دالة إحصائية بين ميكانزمات مواجهة الضغوط والتكيف لعينة الذكور وإجمالي العينة. بينما لم يتحقق صحة الفرض: توجد علاقة ارتباطية ذات دالة إحصائية بين ميكانزمات مواجهة الضغوط والتكيف لعينة الإناث. مما سبق تحقق صحة الفرض الثاني: توجد علاقة ارتباطية دالة في البعد البيئي بين ميكانيزمات مواجهة الضغوط والتكيف. الفرض الثالث: توجد فروق ذات دلالة إحصائية بين عينة الاراسة تبعاً لمتفير النوع في الضغوط البيئية. جدول (r T ): نتائج اختبار (ت) T-test للفروق بين عينة الدراسة تبعاً لمتغير النوع في الضغوط

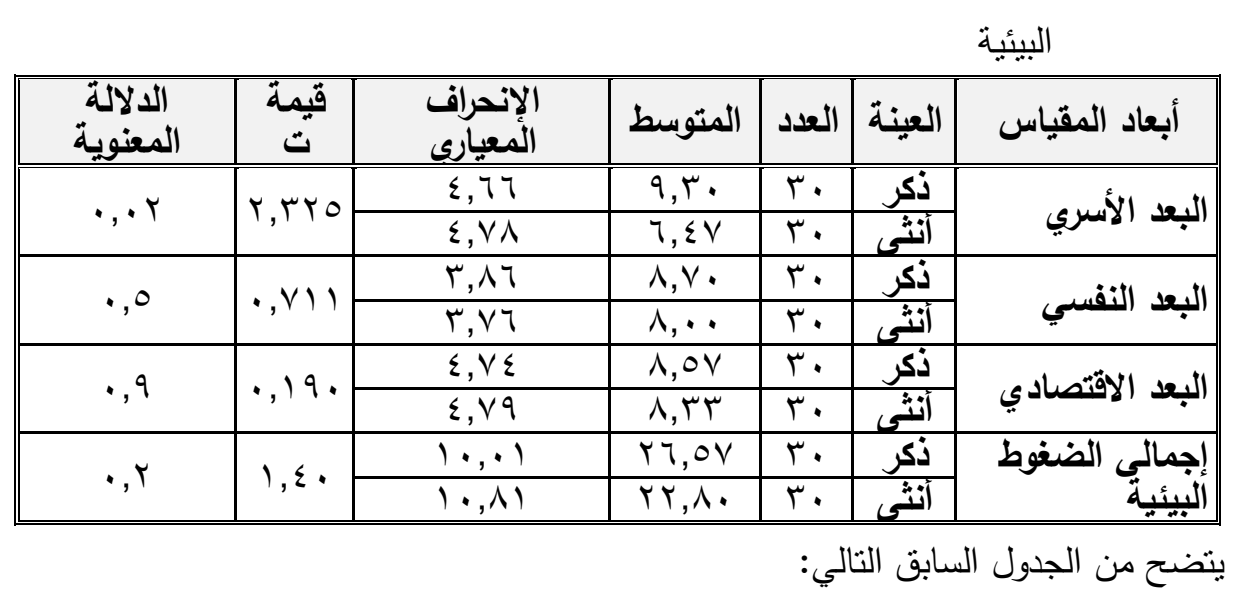
• لا يوجد فرق ذو دلالة معنوية بين عينة الدراسة تبعاً لمتغير النوع (ذكور /إناث) للبعد الاسري

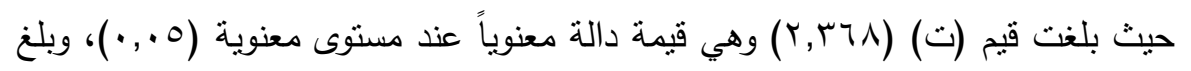

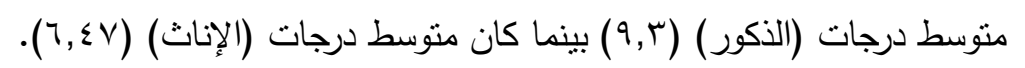

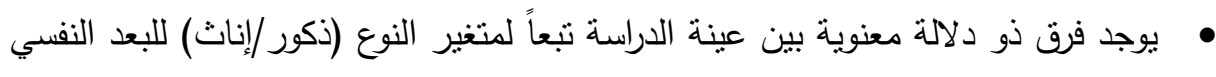

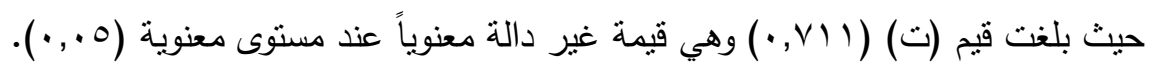


• لا يوجد فرق ذو دلالة معنوية بين عينة الدراسة تبعاً لمتغير النوع (ذكور/إناث) للبعد

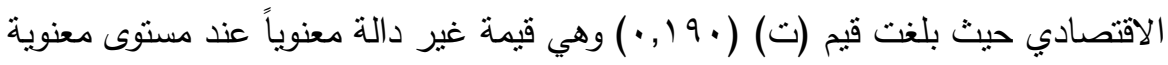

$$
\cdot(\cdot, \cdot 0)
$$

• لا يوجد فرق ذو دلالة معنوية بين عينة الدراسة تبعاً لمتغير النوع (ذكور/إناث) لإجمالي

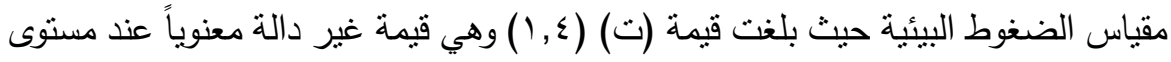

$$
\text { معنوية (0., •).). }
$$

مما سبق تحقق صحة الفرض: نوجد فروق ذات دلالة إحصائية بين عينة الدراسة تبعاً

$$
\text { لمتغير النوع للبعد النفسي. }
$$

بينما لم يتحقق صحة الفرض الثالث: توجد فروق ذات دلالة إحصائية بين عينة الدراسة

تبعاً لمتغير النوع في الضغوط البيئية.

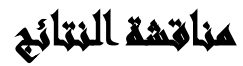

1. توجد علاقة ارتباطية ذات دالة إحصائية بين الضغوط البيئية والتكيف لعينة أسر الأطفال

$$
\text { الذكور المصابين بمتلازمة داون. }
$$

r. لا توجد علاقة ارتباطية ذات دالة إحصائية بين الضغوط البيئية والتكيف لعينة أسر الأطفال

$$
\text { الإناث المصابين بمتلازمة داون وإجمالي العينة. }
$$

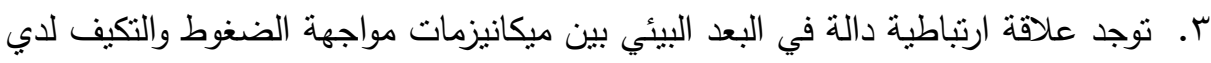

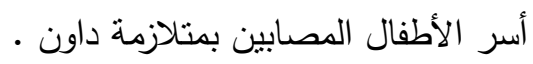

ـ. توجد فروق ذات دلالة إحصائية بين عينة الدراسة تبعاً لمتغير النوع للبعد الأسري لدي أسر الدران

$$
\text { الأطفال المصابين بمتلازمة داون. }
$$

ه. لا توجد فروق ذات دلالة إحصائية بين عينة الدراسة تبعاً لمتغير النوع لباقي أبعاد المقاييس

$$
\text { وإجمالي الضغوط البيئية. }
$$




\section{أهم التوصيات التي خرجت بها الدراسة:}

1-الاهتمام بإجراء العديد من الدراسات حول موضوع التقبل لطفل متلازمة داون من قبل أسرته ومحيطه الاجتماعي الخاص والعام، ومدى احتمالية وقوع الإساءة عليه نتيجة تلك الإعاقة.

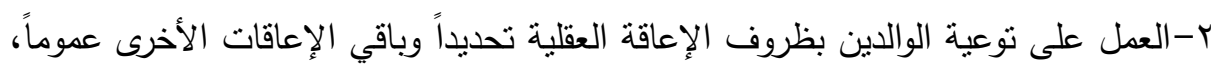
وتتجيعهم على تقل قدرات الطفل المعوق وإقناعهم بإمكانية استغلال هذه القدرات لإنتاج

$$
\text { طفل معوق فاعل. }
$$

ب-تشجيع الأسر التي لديها أطفال متلازمة داون على الاتصال بالمؤسسات الرسمية والأهلية

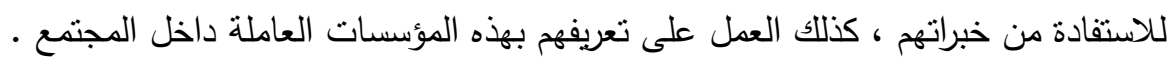

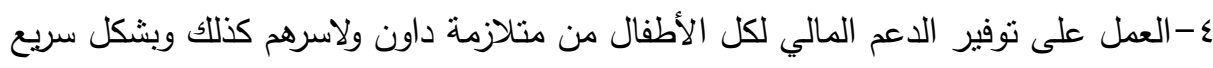

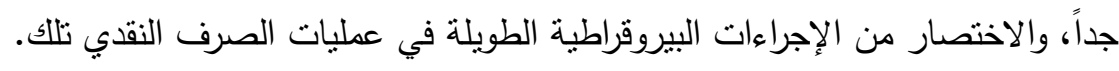
ه- عقد الدورات والندوات التوعوية والإرشادية لأسر الأطفال حول الرعاية التربوية والنفسية

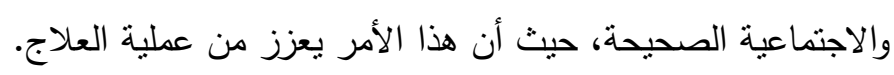

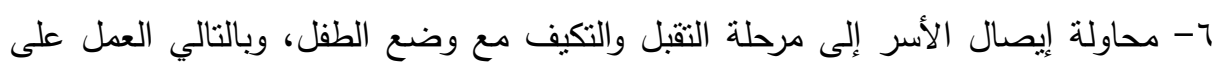

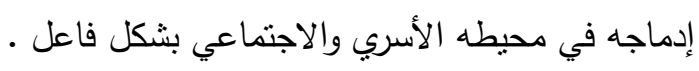

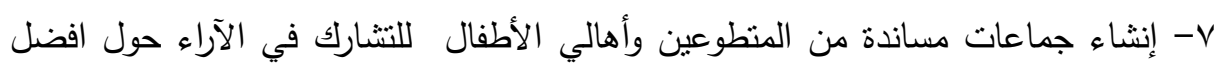
الطرق الخاصة بمساعدة الأطفال وذويهم.

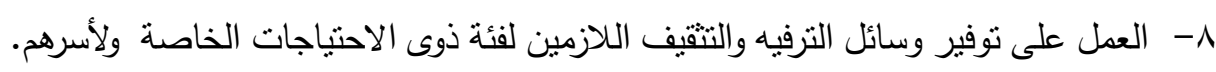

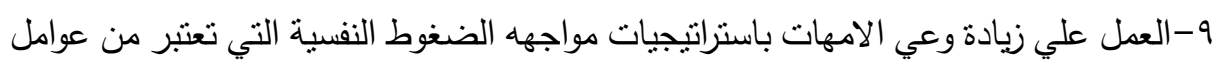
الاستقرار الى تعينها على الاحتفاظ بالتوافق النفسي والاجتماعي في مواجهه الاحداث الضاغطة في حياتها ، والتقليل من اثارها السلبية قدر الامكان 


\section{2all}

إبراهيم عبد اله الزريقات: متلازمة داون- الخصائص والاعتبارات التأهيلية، طا، دار وائل

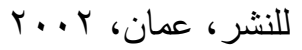

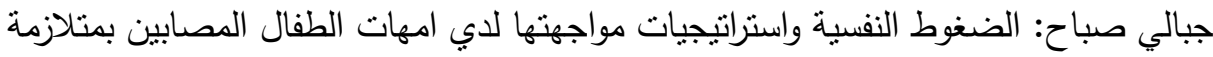

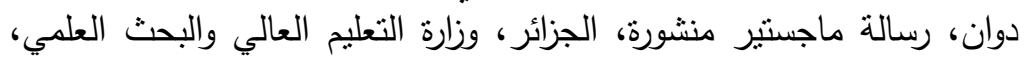

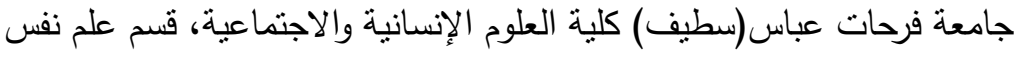

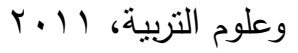

ذياب البداينة: الوصمة الاجنماعية والإعاقة. السلسلة (أ) مجلة العلوم الاجتماعية والإنسانية، 1979 (جامعة مؤنة)

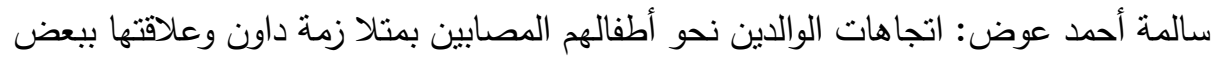

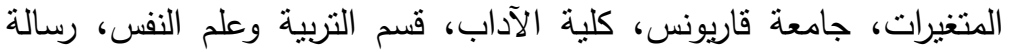

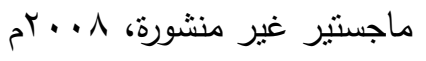

سلوي عبد الحميد الخطيب: نظرة في علم الاجتماع الأسري، المصرية لخدمات الطباعة، القاهرة عاشور عبد المنعم أحمد: المشكلات الاجتماعية والنفسية لامهات اطفال متلازمة دون ، مجله الإيله

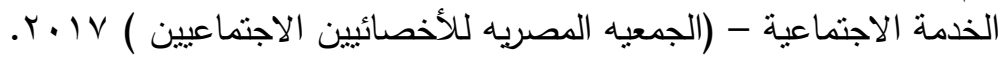

مقبول سيد أحمد فتحي: الضغوط البيئية على الاطفال الايتام في المرحله العمريه من ب إ: 10

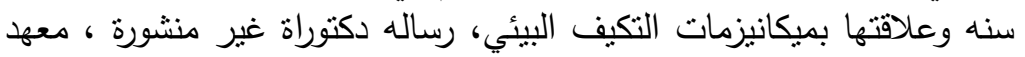

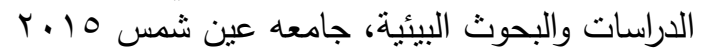

منى محمد قطب: تتميه تمكين الذات لتحسين ساليب لمواجهة لامهات أطفال ذوى متلازمه

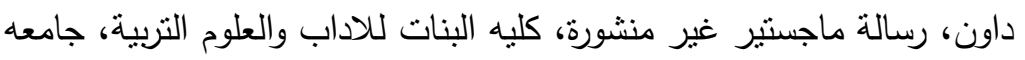

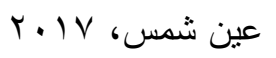

ميادة محمد علي أكبر: العلاقة بين الاتجاهات الوالدية وعلاقتها بالسلوك التكيفي للأطفال

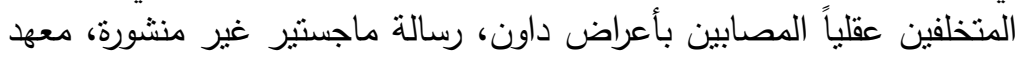

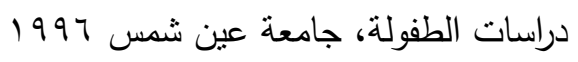


Belchic , J,(1995). Stress, social support, and sense of parenting competence: A comparison of mothers and father of children with autism, down syndrome, and normal development across te family life cycle. unpublished master thesis, the state univerersity, new Jersey .

Dabrowska A Pisula E (2010). Parenting stress and styles in mothers and fathers of Pre-school children with Autism and Downsyndrome, Jozef Piludski university of physical education in warsaw, warsaw, Poland.

\title{
MECHANISMS OF MEETING ENVIRONMENTAL STRESSES AND COPING OF FAMILIES OF DOWN SYNDROME CHILDREN
}

\section{Fawzya A. Hamza ${ }^{(1)}$; Rizk S. Ibrahim ${ }^{(2)}$ and Shaban A. Ahmed ${ }^{(2)}$}

1) Post Gard. Institute of Environmental Studies and Research, Ain Shams University 2) Faculty of Arts, Ain Shams University

\begin{abstract}
In the last few decades, most of children with Down syndrome used not to receive enough medical care. They were deprived from all medical care except for primary ones. It was rarely that injuries, congenital deficits of heart, endocrine glands disorders, sensory weakness, and muscle-skeletal system disequilibrium and problems could be treated. Early intervention, special educational programs, and creative entertainment services were not available. This present study drives at identifying the mechanisms of meeting environmental stresses and coping in families of children with Down syndrome. The researcher defined the sample that consisted of (60) items of families of children with Down syndrome. The researcher used the descriptive (qualitative) 306

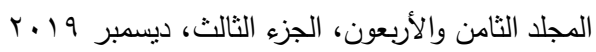


method, applying a questionnaire form on families of children in private centers for those with special needs. This research came into some results which most important were: There was a statistically significant correlation between environmental stress and coping in a sample of males. There was also a statistically significant correlation between mechanisms of meeting environmental stress and coping in a sample of males and the full sample. There were statistically significant differences between study sample items due to sex variable regarding the family dimension. There were statistically significant differences between study sample items due to sex variable regarding the psychological dimension. The research came to several recommendations which most important were: The importance of increasing awareness in society about the reasons of this disease (down syndrome) and the problems that families of children with Down syndrome were meeting and how could society could deal with those children through holding meetings, lectures, programs and using television programs and press communication means. Knowledge and awareness should also be increased towards the psychological and social aspects in those special children, providing services and spiritual potentials for mothers of those children in a sufficient way. There should be more working on increasing mothers' awareness of strategies of meeting psychological stress which is considered as stability factor that assists mothers to keep their social and psychological adjustment in society to encounter stressors of events and incidents in their lives. 